\title{
The Bitter Navajo Language Fluency 2014 Presidential Election Conflict
}

\author{
Larry Roland Stucki, Ph.D.
}

Reading Area Community College, Reading, PA, USA

Copyright $\bigcirc 2017$ by authors, all rights reserved. Authors agree that this article remains permanently open access under the terms of the Creative Commons Attribution License 4.0 International License

\begin{abstract}
The controversial ouster of one of the younger generation's otherwise extremely qualified presidential candidates because he refused to show Navajo language fluency when running for president of the tribe illustrates the dispute between these growing numbers of educated Navajos for whom Navajo is no longer their primary language but who still seek tribal offices and their opponents. Reasons why the opponents seem to be losing this battle are examined and what must be done to give them any hope of reversing this "death" spiral. (A revised version of a paper delivered on April 1, 2016 at the $76^{\text {th }}$ Annual Meeting of the Society for Applied Anthropology held in Vancouver, British Columbia, March 29 - April 2, 2016).
\end{abstract}

Keywords Navajo, Dying Native Language, Cultural Loss, Generational Conflict, Tribal Sovereignty, Ultra-adaptability, Institutional Completeness, Bears Ears National Monument

\section{Dying Language, Dying Culture?}

As in so many Indian tribes, fewer and fewer young people understand the language. And for many tribal elders, the prospect of a president who does not speak fluent Navajo has stoked fears that the language could recede or even die, taking many of the tribe's traditions with it.[1]

Most immigrant groups to the New World initially continue to use their native tongue within the family and close friends especially if they reside in ethnic enclaves. However, as time passes, few of their leaders worry nearly as strongly as certain indigenous Native American leaders do if their young people fail to put in the time and effort needed become fluent speakers of the tribe's native tongue, choosing instead, mastery of English. To understand this discrepancy requires a brief historical review of the changing power relationship that has occurred through time between the New World's original inhabitants and invading Europeans.
Initially, outnumbered in battles, starting with the Spanish, the invaders helped less by guns than by introduced diseases such as smallpox and cleverly pitting one group of natives against another, triumphed.

Prime examples of the use of these two weapons can be seen in the conquests of the Aztecs and Incas in Latin America as well as in the French and Indian War, and the War of 1812. Even choosing the side of the winning combatant by the Tuscarora and the Oneida in the American Revolution did little to help these particular tribes. Nor did the attempt by the Cherokees to become an integral part of the new nation through their leaders' enthusiastic embrace of the legal system, religion, language and lifestyle of the victorious Americans. Even their victory in the Supreme Court decision against removal from their lands did not stop President Andrew Jackson from defying Chief Justice John Marshall and ordering their forced removal to lands west of the Mississippi River.

With the end of the Indian wars, the various defeated tribes were confined to reservations where the oft-practiced ideology that "the only good Indian is a dead one" was replaced by "kill the Indian, save the man." And, to hasten the process of assimilation, children were taken away from their parents and sent to boarding schools often at great distances away from their families and, while kept there, severely reprimanded or punished if they dared speak to each other using their native tongue.

However, such strong measures of suppression though often blamed as the primary causal factor for the rapid decline of fluency in the rising tribal generation, as the linguist John McWhorter points out:

... in reality, just as often the reason groups abandon their traditional languages is ultimately a desire for resources that their native communities do not offer.... The language of the dominant power - written, spoken by the wealthy, and broadcast constantly on radio and television - quite often comes to be associated with legitimacy, the cosmopolitan, and success. Almost inevitably, the home language is recast as, basically, not that - and thus antithetical to survival under the best 
possible conditions.[2]

For example, the young boarding school students quickly discovered the usefulness of English, not only as a lingua franca as they formed friendships with members of many other tribes, but even more importantly as a necessary tool in gaining successful social and economic access to the rewards of the surrounding outside world.

Thus McWhorter in using the Native American situation as an example makes the following prediction:

Before the arrival of Europeans, there were about 300 separate languages spoken by Native Americans in what is today the continental United States. Today, 1/3 of those languages are no longer spoken, whereas all but a handful of the rest are spoken only by the very old and will surely be extinct within a decade or so.[3]

And even in the surviving "handful", the growing number of the younger generation that have placed little value on becoming fluent in their native language is alarming to tribal educators and politicians. Thus on the Navajo Reservation by 1966:

Tribal educators were growing alarmed at the number of Navajo children who were not being brought up speaking the language. At the time, they estimated that one out of every five Navajos under the age of five did not know their language or only knew a few words or phrases.[4]

In an attempt to reverse this decline the editor of the Navajo Times that December decided to begin a regular column to teach non-Navajo speaking Navajos how to speak the language. Lessons continued for almost a year and were praised by many for the effort. However, to have much value they required help from a friend or relative to get the pronunciation right and there was little evidence that these lessons succeeded in stopping the fluency decline. A second greater, full-page (complete with traditional stories) attempt a decade and a half later, despite receiving much praise, was also soon abandoned.[5]

The decline in younger generation fluency continued after that time and by 1994, educators at Navajo Community College (now Diné College) bemoaned the fact that over half the children entering the preschool program on the reservation spoke no Navajo.[6] This was followed 12 years later by the alarming news that a December 2016 pre-test data set of 3,062 BIE and grant school students who had taken the Oral Diné Language Assessment Test that fall had revealed to reservation educators that only 8 out of the 3,062 students tested were fluent in Navajo. [7] And, the following April, a more complete preliminary report of these fall 2016 test results from all 31 BIE schools in the Navajo District was released reporting that "about 95 percent of the students lack fluency in the Navajo language."'[8]

Sensing that it was now or never to mount a massive campaign to prevent the Navajo language from joining the growing graveyard of "dead" Native American languages,
Jennifer Wheeler, the Navajo language and culture education specialist for the Navajo district of the Bureau of Indian Education, organized the first large-scale Diné Language Symposium which attracted more than 150 teachers, staff and administrators from the BIE, public and tribal controlled schools, along with partners from tribal and state universities.[9]

In addition to exploring various classroom strategies and parental involvement Wheeler said:

...the effort to revitalize the Diné language needs to extend past the classrooms to halls, playgrounds, neighborhoods, bus rides and homes, as well as to academic standards, policies and laws.

We really need to roll up our sleeves and save our language ...[10]

Will she and the other educators succeed? Historically such attempts to revive a language that is no longer the primary language of the rising generation have failed with the one exception of Hebrew, now the daily language of Israelis. Thus, as the linguist John McWhorter points out, "these efforts, laudable as they are, face many imposing obstacles, posed in large part by the realities of how languages live in the world as we know it," one of the most important being:

... most languages are actually clusters of dialects. The form of a dying language taught in school is often a single, standardized variety, which can be quite different from the various dialects that constitute the "language" as it actually exists. If there is still a healthy population of people speaking the language natively and well, this "school" variety that children learn may sound rather sanitized and even imposed from without. This is a special problem in communities where the impending death of the language is a symptom of historical oppression by a surrounding power...[11]

Certainly, frantic attempts to reduce fluency declines in the rising younger generation on the Navajo reservation are in part motivated by the memories that older Navajos have of their boarding school experience and by the strong desire of tribal leaders to continue to gain further recognition from the federal government that though once defeated, they are still a "sovereign nation." However, an even stronger motivation appears to be the fear that key elements of Navajo culture will be forever lost if the language dies, a controversial hypothesis[12] first proposed by the anthropological linguist Benjamin Whorf and his mentor Edward Sapir and widely endorsed by many Native American leaders and educators. Thus, following the chaotic 2014 presidential election, in a 2015 referendum about possibly amending the fluency requirements for the two top elected Navajo officials, the Navajo Nation's very first president, Peterson Zah argues that:

The Navajo language is on self-identity. Too many Navajo men and women sacrificed their lives to ensure 
the language was preserved for the future generations, for us, and for those to come. ... Now it is our turn. We, too, must be responsible for protecting this Great Covenant.

Vote against the amendments to the Navajo language fluency requirements during the referendum election. Our Navajo language holds great teachings that must be preserved. It is important that our leaders are able to speak and understand the Navajo language because it is our foundation, the core value of who we are as a people and a nation.

We should continue to be proud and let's all join hands as elderly folks and teach the young people the Navajo culture and by all means teach them the Navajo language. That's the way to survive and that's the way to keep us going, not to diminish the Navajo language.[13]

Dying Language, Dying Culture? The following case history/participant-observation approach [14] will provide some possible answers.

\section{Voter Unrest}

Put all the worst elements of governments all over the world together and that is Navajo tribal government. [15]

The above quote from a letter to the editor of the Navajo Times from the Chief Executive Officer of the Native American Indian Embassy (Albuquerque) on January 16, 2014 summarized the feelings of many Navajos as the year to elect a new president began. In addition to failing to adequately deal with the chronic problems of crime, poverty, alcoholism, bad roads, unequal access to safe water, electricity, etc.; beginning in the year 2010, 142 tribal leaders including "77 of the 88 sitting Council delegates ... additional elected and appointed officials and staff members ... the controller, the attorney general, and a former president" were charged with "converting millions of dollars in discretionary funds to personal use." Such financial assistance funds had been given to these individuals "to provide assistance to citizens with emergency needs" not for their own perceived needs and desires or those of their family and friends.[16]

According to the prosecutor, this theft resulted in a "disparity of wealth whereby the vast majority of the nation lives precipitously on the edge of poverty while those in positions of authority have amassed considerable wealth." However, the original criminal charges were dismissed and replaced with civil suits for all but the 17 worst offenders who were accused of illegally taking "nearly $\$ 850,000$ " from the financial assistance program. And by the first of March 2016, 14 of the 17 criminal cases had gone through the courts and all had "yielded convictions, either through guilty pleas or pleas of no contest."[17]

Thus, as the time to choose new presidential candidates approached, in a 2014 letter to the Navajo Times editor, Karletta Chief, an Assistant Professor at the University of Arizona, in answer to a question posed by a previous reader wondering if new candidates could even be found who would "serve, lead, protect, and represent the Navajo people honorably," be "accountable and transparent," possess "integrity and honesty," and have "the education, experience, and the knowledge to move our people forward", stated that they could come from:

...the many educated, honorable, young people out there who have been raised with values of honesty, integrity, and respect. The challenge is lack of opportunities and welcoming in of this new generation. It is time to ... welcome the children you have sent to be educated, to now serve our people, and to lead us into the new generation.[18]

In addition to the current president, Ben Shelly, who was seeking reelection, and a former two-term president, Joe Shirley, Jr., whom tribal law now permitted to run again, 15 new candidates entered the race, including an extremely qualified representative of the younger generation, Chris Deschene, who would soon find out if the time had finally arrived for such a welcoming by being not only a "straight-A student and varsity athlete [in high school]" but also because he:

...was one of the very few Native Americans to be accepted into the prestigious U.S. Navel Academy in Annapolis. Upon graduation he was commissioned as a $2^{\text {nd }}$ Lt. in the U.S. Marine Corps. While in the Marines, he served as an infantry and reconnaissance officer with two tours in the Persian Gulf. After 10 years of honorable service, Chris left with the rank of major and returned home. He went on to graduate school at Arizona State University to earn a master's degree in engineering and a juris doctorate in law. ... In 2008, Chris was elected and served as the state representative from the Navajo Nation in the Arizona House of Representatives. In 2010, Chris campaigned successfully to be the democratic nominee for Arizona's Secretary of state and the first Native American to do so.[19]

By mid July the primary campaign was clearly bringing out the divide between the older and younger candidates as seen in a letter to the editor urging:

Younger voter, the future is here. Voice your concerns, stand up and be counted. It's your time to carry the ball, like it or not. Be aware of the old guard police "Drink my poison from the political Kool Aid of corruption." Vote![20]

And when the votes in the August primary were counted, not only many younger voters but also older ones seeking a radical change in tribal leadership had thrown enough support behind Chris Deschene to give him a second place 
finish in the primary behind Joe Shirley, Jr. to face Shirley as his opponent on the November Presidential Election ballot. However, as it soon became obvious to many that Deschene had a very strong chance of beating Shirley in the November election, two of his former primary rivals, Dale Tsosie and Hank Whitethorne began an attempt to have Deschene's name removed from the final ballot even though neither of them stood high enough in the vote count to take Deschene's place as Shirley's opponent on the ballot.

Ostensibly, their challenge was motivated by Deschene's own admission that his command of the Navajo language was far from perfect while Navajo law required the tribe's president to speak the language fluently. Thus, as succinctly contained in the following quote from a New York Times article by Ian Lovett:

Thus Mr. Deschene's candidacy has exposed a deep divide within the Navajo nation, the country's largest Indian tribe, about the role that language should play in modern Navajo society, the tribe's direction in the new millennium and how traditionally Navajo the tribe's leader needs to be.

As in so many Indian tribes, fewer and fewer young people understand the language. And for many tribal elders, the prospect of a president who does not speak fluent Navajo has stoked fears that the language could recede or even die, taking many of the tribe's traditions with it.[21]

I, myself, while a visiting professor at the Navajo Community College (now Diné College) at Tsaile, Arizona in 1994, vividly remember the dismay expressed by the Navajo language professors when it was announced that over half of the students entering Navajo reservation schools could not speak Navajo (at least not "fluently").

Initially, the challenge by Tsosie and Whitethorne was dismissed by the Office of Hearings \& Appeals since tribal election law clearly stated that such a challenge must be made by a competing candidate or candidates within a 10 day grievance period after the candidate whose qualifications are being challenged files his or her application to run for office, not after the election has taken place! Thus, according to tribal election law, after the primary election totals were announced only the first place finisher, Shirley, now had had a 10 day period to, himself, file a challenge against the second place finisher, Deschene, which option he had failed to take.[22]

Not accepting this dismissal, Tsosie and Whitethorne made an appeal to the Navajo Nation Supreme Court that agreed to hold a hearing on the fluency challenge on Friday, September 26, 2014 at 9 a.m.[23] This created a major problem for the Navajo Election Administration which under tribal law had to send out absentee ballots 30 days before the November $3^{\text {rd }}$ general election since the company printing the ballots had also set Friday, September $26^{\text {th }}$ as the final day it initially said it could wait before learning which final two presidential candidates' names should appear on the printed ballot.[24]

The Friday Supreme Court Hearing did not go well for Deschene who was ordered to appear before the Office of Hearings and Appeals on October $3^{\text {rd }}$ [25], but the Navajo Board of Election Supervisors by a $4-2$ vote at a special meeting on Tuesday, September $30^{\text {th }}$, decided against delaying the November $4^{\text {th }}$ General Election even for the office of tribal president. Thus, as quickly as possible, ballots were printed still listing Deschene as Shirley's opponent for the top tribal position.[26]

On October $8^{\text {th }}$ the Navajo Nation Supreme Court issued its formal opinion that the post election challenge to Deschene's right to remain on the ballot would be allowable if it could be proved that he had falsely stated on his application that he was "fluent" in Navajo.[27] However, as Pauletta White in a letter to the Editor on October $2^{\text {nd }}$, pointed out:

Is there a definition of "fluency?" How many of our children and grandchildren, both on and off the reservation, are truly fluent?

The language choice among our children, and among most of us, is English. Even those of us who claim to be fluent, will come across a grandma/grandpa who will tell us that we aren't saying things properly In Navajo. I commend Mr. Deschene for working towards "fluency."[28]

And though the Navajo Supreme Court tried in vain to force Deschene to take a Navajo fluency test they had devised, as the writer of another Letter to the Editor a few weeks later asks:

The word "fluent" is so vague and open to many interpretations ... by whose standard of testing will be used to determine fluency henceforth? So many dialects, slang, and colloquialisms exist within Diné bizhaad.[29]

Expressing the depth of anger shared by many of Deschene's supporters that his refusal to take what he felt was an unfair "fluency" test that was not required to be taken by any of his other primary opponents, including the two challenging losing ones, would now possibly lead to his removal from the ballot, Harvey Begay in a published Letter to the Editor on October $16^{\text {th }}$ wrote:

The decision by the Navajo Nation Supreme Court is a travesty of justice for Chris Deschene. Any man or woman who goes to a military academy and receives a commission to lead warriors into battle has definitely earned a right to lead a nation or state in the civilian sector. ... The requirement that a president be fluent in Navajo is absurd. ... We are a decade and a half into a new century. The old guards and disgruntled presidential candidates are grasping on to the past. ... Time marches on (forward) and not backwards. Accomplishments in the educational field evidently don't mean anything. Hanging around the trading post 
and going to the local Navajo social song and dance has more credence in attaining a leadership position. ... Young people, listen up! Do not let the old guards close the door on your future. ... The world has changed; we are no longer an isolated nation within the continent. We are part of a global economy.[30]

Early voting for the General Election was permitted but on October $23^{\text {rd }}$, just 11 days before the November $4^{\text {th }}$ final day, the Navajo Supreme Court ordered the Navajo Election Administration and the Navajo Board of Election Supervisors to postpone the on-going election, to reprint new ballots and replace Chris Deschene with the Russell Begay, the candidate receiving the third highest vote total number of primary election votes on the November $4^{\text {th }}$ ballot.[31]

However, the Navajo Board of Election Supervisors responded that this would not be possible since:

... there is no law to postpone/terminate an on-going election with over 10,000 confirmed ballots since this would violate voters' rights. To reprint new ballots and place R Begay's name on the ballot was not possible for there were no funds to pay the printing company and funds had to be approved by the NN [Navajo Nation] Council. There was also a process for qualification of $\mathrm{R}$ Begay and his running mate including the 10-day grievance period. All this could not be done immediately.[32]

The refusal of the Navajo Board of Election Supervisors to obey this Navajo Nation Supreme Court order won large support from Deschene's many supporters who included not only the vast majority of young voters but also many veterans from all military branches including a revered Navajo Code Talker who "acknowledged that he struggles with speaking English and Navajo" as well as many Chapter leaders as was demonstrated in a series of rallies and marches arranged by the Navajo Voters' Rights Coalition, ('an alliance to ensure that the voice of the Diné people is respected").[33]

But even more important was an 11-10 vote by the Navajo Nation Council at midnight on October $23^{\text {rd }}$ to amend language requirements to allow the voters to determine whether a candidate is fluent in the Navajo language that would have allowed Deschene to remain on the ballot if the current tribal president Shelly would sign the bill they then submitted to him. (At first, according to what I was told by a tribal administration insider, Shelly had planned to sign the bill but after several key visits from those opposed to Deschene, on October $28^{\text {th }}$, he vetoed it.) Quickly, Council Delegate Leonard Tsosie tried to get enough signatures for a special November $3^{\text {rd }}$ Council session, one day before the election, to attempt to get enough votes to override Shelly's veto, but failed.[34]

On October $31^{\text {st }}$, angry with the Navajo Board of Election Supervisors who had rejected his demands, Herb Yazzie, Chief Justice of the Supreme Court, removed Tom M. White Jr. and Norman Begay from the election board and banned them for running for any tribal position for five years. And since they were both on the current ballot for Tribal Council seats, he disqualified them as candidates and cancelled the election in both of their districts.[35]

Thus on Election Day, those who had not yet voted were told not to mark the ballot for either presidential candidate since any such votes would not be counted.[36] However, many voters marked their ballots anyway and according to anonymous sources at the chapters, votes for Deschene outnumbered those for Shirley by about four to one although this ratio may have been distorted "because Deschene's supporters, "voted as a form of protest whereas Shirley's supporters, who will still get a chance to vote for him, did not."'[37]

A new date was now set for a special presidential election, December $23^{\text {rd }}$, although it was not clear whether or not White's and Begay's current opponents would automatically be declared winners or would have to face the third highest vote getters in their districts as replacements for White and Begay.[38]

Despite Shelly's veto of the amended language bill, Deschene's supporters had not yet given up. Thus a second petition was being circulated among Council members to hold a special session on November $13^{\text {th }}$ and $14^{\text {th }}$, which again would attempt to override Shelly's veto.[39] And in addition to volunteers circulating petitions at chapter houses to put Deschene's name back on the December $23^{\text {rd }}$ ballot, on November $6^{\text {th }}$ a special meeting of "To Nanees Dizi Local Governance" was to be held that evening to consider resolutions to recall Council Delegates Joshua Lavar Butler and Katherine Benally who had "voted against amending the language amendment."'[40]

A challenge by another candidate, (who had lost the primary election), to the placing of Russell Begaye's name on the December $23^{\text {rd }}$ ballot as Shirley's new opponent, created more election chaos at this point. Begaye was now accused of being an unqualified replacement for Deschene because of his decision to join with other Navajo Oil and Gas shareholders who had filed a lawsuit in federal court trying to overturn a decision by the Navajo Supreme Court.[41] Since it was now uncertain when the Office of Hearings and Appeals (OHA) would make a decision about whether or not this act of "disloyalty" to the Navajo Nation made Begaye unqualified to run for the office of president and the subsequent possibility of an appeal of any OHA decision by the loser to the Navajo Nation Supreme Court, the presidential election would now have to be postponed until sometime in 2015.[42]

On Monday the $23^{\text {rd }}$ of November, the OHA cleared Begaye of the charge against him but the possibility of an appeal by the losing parties to the Navajo Nation Supreme Court still prevented the rescheduling of the presidential election.[43] And on December $3^{\text {rd }}$ the Navajo Voter Rights Coalition gathered large numbers of supporters who then marched to the Navajo Nation Council Chamber to protest the treatment of Deschene by his opponents.[44] 
To the dismay of many, Myron McLaughlin, who had filed the original complaint against Begaye, also on the $3^{\text {rd }}$, said he planned to file an appeal of the OHA decision to the Navajo Nation Supreme Court.[45] And a new problem delaying the election arose when the company that would be printing the special election ballots refused to print any until the Council would approve the needed funding. Edison Wauneka, the sole surviving election official after the Supreme Court removed all members of the election board, said he needed $\$ 317,000$ to pay for the printing of ballots and pay for the poll judges.[46]

Wauneka was now being caught in the middle between the Supreme Court (and OHA) and a frustrated Council Committee whose spokesman, Leonard Tsosie, criticized Wauneka for instructing his staff to tell people to not cast any vote for either tribal presidential candidate and further alleged that Wauneka and Chief Justice Herb Yazzie had joined efforts "to commit conspiracy for not releasing election figures from the general election in which thousands of people" had already cast votes for Deschene "that went uncounted", which according to the Navajo Voters Rights Coalition numbered over 30,000 votes.[47]

Feeling the pressure from many angry Deschene supporters and never again wanting to fight a fluency battle, on December $23^{\text {rd }}$, the Navajo Nation Council by a unanimous vote "passed legislation 0289-14 that amends election law and allows voters to decide if a Navajo Nation presidential candidate is considered fluent".[48]

Adding to the election confusion came the surprise announcement on December $29^{\text {th }}$ that Chris Deschene had "submitted a motion to vacate the Office of Hearings and Appeals orders and be reinstated as a candidate for Navajo Nation president" based upon the fact that the Chief Hearing Officer Ritchie Nez had been removed from office on October $31^{\text {st }}$ by the Navajo Nation Supreme Court because he was not licensed to practice law in Utah, Arizona, or New Mexico as required by Navajo law. Thus, Deschene's attorney argued that Nez's rulings on Deschene's presidential candidacy was void.[49]

The next day, December $30^{\text {th }}$, Deschene again received help from the Navajo Nation Council that voted "to just throw out the election held in 2014 completely and start over again with a primary to be held on June 2 and a special election to be held August 4".[50] However, Deschene's hope for a reinstatement on any forthcoming presidential ballot faded when the following day, December $31^{\text {st }}$, President Shelly vetoed the December $23^{\text {rd }}$ bill passed by the Council to let voters not the Navajo Nation Supreme Court decide if a presidential candidate meets the "fluency" requirement. And by not signing the Navajo Nation Council resolution throwing out the 2014 election and "starting-over-again" bill before the last day of the year ended, it too died on that day.[51] Also failing to gain President Shelly's signature before the start of the new year, was a bill passed by the Navajo Nation Council that would grant pardons to those individuals removed from the Navajo
Board of Election Supervisors and reinstate them to their former positions.[52]

It was now obvious that no election could now be held prior to the end of Shelly's term in office on January $13^{\text {th }}$. This created a major dispute as to who should serve as an acting president until a new election could finally be held, with the Department of Justice having the legal opinion that Shelly should continue serving in this new role while the Legislative Council issued an opinion that the speaker of the Council should serve as the interim president.[53] However, an agreement was reached between Shelly and representatives of the council on January $9^{\text {th }}$ that he could continue serving as president until a new president was selected.[54]

Frustrated, Tsosie and Whitethorne made an appeal to the Navajo Nation Supreme Court to remove Edison Wauneka from his position as director of the tribe's election office "for failure to hold the election by the deadline set up by the supreme court" and also failure to remove those council delegates "who voted to approve a new primary and general election." As expected, Chief Justice Yazzie honored this request and scheduled hearings to begin on February $6^{\text {th }}$ and offered Shirley and Begaye the opportunity to offer their own briefs also on the $6^{\text {th }}$. [55] Thus in response, when the Navajo Nation Council met for its winter session on January $26^{\text {th }}$, one of the first bill to be presented was to amend the election code to "allow language proficiency to be determined by the people voting in favor of the person upon the right and freedom of the Diné to choose their leaders." This amendment to the election code "would apply to all elected positions including the office of the presidency and vice presidency."[56]

Although there were now changes in the Council membership following the November election, there was no hint that its leaders had abandoned their earlier desire to restart the election process for tribal president with a new primary with Deschene as a candidate. Thus, a suggested resolution to hold a single election on March $24^{\text {th }}$ "between Joe Shirley Jr. and Russell Begaye along with a write-in candidate" was not seriously considered.[57]

Nevertheless, one important obstacle holding back any kind of election soon being held, was removed when the Council passed a resolution that was then signed by President Shelly providing $\$ 317,999$ to the election office so that ballots could be printed. But still to be resolved was whether this money was to be only used for a new primary election as the Council's resolution had firmly stipulated or could be used to finance an election between Shirley and Begaye as the Supreme Court had ordered.[58]

A brief submitted to the Supreme Court by the Navajo Nation Department of Justice strongly recommended to the court to explore the idea of enacting a "consensus-based resolution [that] Navajo people have used throughout their history to bring people in dispute back into harmony." However, in his brief to the court, Shirley strongly rejected the idea of such a meeting, saying it would be "an exercise in 
futility" and that any further delay in holding the election would be especially unfair to him and his supporters. Also, Tsosie and Whitethorne strongly opposed any consensus or court decision that would put Deschene back on the ballot.[59]

By February $19^{\text {th }}$, although the Supreme Court had been delaying its decision, it had already ruled out "the idea of allowing the various sides to come together and try to come to an agreement" and against allowing oral arguments.[60] The long awaited decision, coming the very next day, siding with Shirley, Tsosie, and Whitethorne, brought angry charges from Rebecca Nave Cling, at a protest rally of the Navajo Voters' Rights Coalition, comparing Chief Justice Yazzie's "leadership and behavior to Vladimir Putin, President of Russia."[61] By now it was obvious to most Navajos that although there were supposed to be three judges on the Supreme Court, at the present time one position was vacant and the remaining other judge merely went along with Yazzie's decisions. As Anthony Allison at the same protest rally said about Chief Justice Yazzie, "He is a dictator."[62]

Not only was an election between Shirley and Begaye now scheduled for April $21^{\text {st }}$, but the court also invalidated the Council's resolutions, the first being to start the election over again with a primary and the second, the pardoning of the former members of the Navajo Board of Election Supervisors. Thus the Supreme Court "ordered the election for the six vacant election board positions to be held with the presidential election.”[63]

A March $13^{\text {th }}$ special session of the Navajo Nation Council was now planned where a vote would take place on a bill sponsored by Council Delegate, Dwight Witherspoon to allow the $\$ 317,999$ the Council had allocated to the election office to be used to finance an election between Shirley and Begaye as the Supreme Court had ordered rather than to be only used for a new primary election as the Council's earlier resolution had firmly stipulated. Predictably, the Navajo Voter's Rights Coalition planned to attend the meeting to "oppose and pressure members of the Council not to pass [the] bill."'[64]

As expected the protesters showed up including one bearing a sign that read in Navajo, "Herb Yazzie you're not the boss" indicating the growing anger of many toward Chief Justice Yazzie.[65] "After hours of debate" by a vote of 19 to 1 , the Council instead of allotting money for a new primary election, agreed to authorize $\$ 317,897$ for the April 21 election but then, on a closer 12 to 8 vote, the Council attached an amendment that the money should be first used to pay for a referendum to be held before the special election that would ask Navajo voters if the Navajo fluency law should be amended. However, Wauneka told the Council that the April $21^{\text {st }}$ election would happen "regardless of the Council's decision on the bill, because his office would get funding for the election ballots through operational funding from the three branches of government."'[66]

However at this point, to the dismay of the Council's opponents, acting president Shelly signed into law on March $16^{\text {th }}$, the Council's authorization of funds to hold the April $21^{\text {st }}$ election but only if it would be proceeded by a "fluency" referendum. This led Edison Wauneka, the director of the Navajo Election Administration, on the $17^{\text {th }}$ to "put the election informally on hold" while he waited to see if the Supreme Court would strike the controversial "fluency" amendment down. And as expected, an attorney for Whitethorne and Tsosie appealed to the Supreme Court to declare that the Council's legislation be declared invalid and that the money approved to be used first for a fluency referendum be instead used for the April $21^{\text {st }}$ run off election between Shirley and Begaye. Shirley, also, strongly criticized not only the Council but also acting president Shelly for having signed the Council's latest resolution.[67]

However, the need for a temporary hold did not last too many days since that Friday, March $20^{\text {th }}$, the Supreme Court invalidated the Council's December resolutions calling for a new special primary and general election and the pardoning of the election supervisors who the Court had held in contempt. And it ordered the April $21^{\text {st }}$ election to proceed as planned and that Wauneka "be protected from any adverse action by the council for carrying out orders of the supreme court." Also, in addition to casting votes in the presidential race, voters would vote on candidates to fill the six positions, now declared vacant, on the Navajo Nation Board of Election Supervisors. But in a surprise to the Council's opponents, the court did not strike down the Council's proposed fluency referendum and its authorized funding or force it to specifically approve funding so that the April $21^{\text {st }}$ election could proceed without further delay. Nor did it honor the request by Whitethorne and Tsosie "to hold members of the tribal council in contempt for passing resolutions that would delay the election." However, the Court ordered the election office to use its "available operating funds" to pay for the printing of the needed ballots and directed the acting controller of the Nation "to identify and transfer" any additional money needed for the April $21^{\text {st }}$ election to the election administration.[68]

Meanwhile, the dismissed members of the 2014 Navajo Board of Election Supervisors in a paid advertisement in the Navajo times on March $12^{\text {th }}$ strongly condemned their treatment by Chief Justice Yazzie who they said not only had violated a number of tribal election laws but had also denied them their right to due process to explain to the court why they felt that they could not legally follow his orders. And the strength of support for the argument presented by these now dismissed election officials was seen in the March $26^{\text {th }}$ issue of the Navajo Times where it was reported that "a majority of Navajo chapters and agency councils (55 chapters and 3 agencies) have passed resolutions requesting the removal of chief justice or judicial reform"... "usually by a large majority." And, in addition to criticism about Yazzie's rulings in the current election were added complaints about other unpopular judicial decisions he had made in the past.[69] Also, not helping his rapport with the Navajo Nation Council was his rejection of requests by the Council 
to meet with them to "talk things out as a way of practicing the Navajo method of peacemaking."[70]

One final desperate attempt to postpone the April $21^{\text {st }}$ election occurred on April $14^{\text {th }}$ when four of the now dismissed former members of the Navajo Nation Board of Election Supervisors with the support of a 19 to 1 vote by the Navajo Nation Council joined by interim President Shelly asked Window Rock District Court Judge Carol Perry to issue "a temporary restraining order to stop Tuesday's election so that a referendum could be held first to determine the Navajo fluency question." Perry, then, having spent three hours hearing testimony, told the former election board members that she would release her decision "soon."[71]

To the dismay of Edison Wauneka, the remaining election official, this decision came just three days before the election was scheduled to be held, as Perry "issued a ruling halting the election until the referendum could be held." Disobeying her order could put him at risk of jail time or a "stiff financial penalty" but so could disobeying the Supreme Court order to hold the election as scheduled. Adding to his dilemma was Judge Perry's defense of her ruling that it "did not overrule the Supreme Court but addressed solely the issue of whether the election should be held after the referendum, as the Navajo Nation Council wanted, or whether it could be held before the referendum" adding that the Supreme Court had not addressed this issue in its ruling.[72]

Wauneka, shortly after Judge Perry's ruling was issued chose not to follow it but instead filed an appeal against it to the Supreme Court on Monday, the day before the scheduled election. An "expedited" session was then held where Chief Justice Yazzie, joined by Associate Justice Eleanor Shirley and William Platero, a district court judge, after a 70 minute hearing declared Perry's ruling "null and void."[73]

Bill Donovan, the Navajo times reporter, when describing this "last minute "plot" states that:

Although this did not come up directly in either the Perry ruling or the Supreme Court appeal, there was an indirect nod that one reason why people wanted the referendum to be held first was so that if the Navajo voters approved changing the language of the Navajo fluency requirement, it would allow Deschene to run either as a full candidate or as a write-in candidate.[74]

The day Joe Shirley Jr. had for many months been fighting for finally arrived but, to his dismay, the opponent he had possibly felt would be easier to beat than Deschene, was leading him "by about 10,000 votes with all precincts reporting late Tuesday."'[75] As the newly elected president, Russell Begaye, talked to The Associated Press about why he had beaten his rival; he felt it was because large numbers of Navajos were tired of living on a reservation where half the workforce was unemployed and many homes still lacked such basic items as electricity and running water. Thus, "Across the board, people wanted a new leader. They didn't want to be stuck in the same rut. They wanted to move forward."'[76]
And a month later in an apparent attempt to ease the frustration of many of Deschene's supporters, it was reported in the Navajo Times on May $14^{\text {th }}$ that:

The new Begaye-Nez administration will be run by a lot of people who may not be familiar to most tribal members.

In selecting those people who will run the tribal government for the next three and a half years, Navajo Nation President Russell Begaye and Vice-President Jonathan Nez have chosen young Navajo men and women who have not been connected with former administrations of the tribal government.[77]

The election was over but anger toward Chief Justice Yazzie was not. Thus, on Tuesday, May $5^{\text {th }}$, the Council's Law and Order Committee, after considering 392 submitted comments urging Yazzie's removal as opposed to only 20 recommending his retention, supported Council Delegate Leonard Tsosie's bill to remove the Chief Justice from office for alleged "malfeasance, misfeasance, or serious neglect of duty." With this committee's approval, a special council session to debate and vote on Tsosie's bill was tentatively scheduled for May $19^{\text {th }} \cdot[78]$

On May $13^{\text {th }}$ Yazzie, facing overwhelming odds not only from the Council but also from a majority of Chapters, announced his retirement beginning at 5 p.m. on Friday, May $15^{\text {th }}$, leaving Associate Justice Eleanor Shirley as the only remaining member of the Supreme Court. And, quite possibly, finally wanting to make public his own bias in the fluency controversy, his released statement published in the Navajo Times was in written Navajo with no English translation despite his obvious English language skills having served in the U.S. Army, graduating from Arizona State College of Law, and being a member of the Utah State Bar and the Navajo Nation Bar Association.[79]

Although the fluency election had by now been tentatively scheduled to be held in June, the Navajo Board of Election Supervisors had been holding off setting an actual date for it while they waited to see if the Council would be placing other questions on the ballot for the voters to decide. But rather than waiting much longer to see what the Council might want to add, in the last week in May, they decided to set a July $21^{\text {st }}$ election date with the single fluency question on the ballot. And wanting to "prevent a movement if the measure passes to cancel the results of the past presidential election and hold another special election that would allow Deschene to run", the election board also "passed a resolution saying if the voters approve the change in tribal law, it would only apply to future elections."'[80]

Ironically, Edison Wauneka, still director of the Navajo Election Administration, announced that his staff was "having a problem translating the question that was approved by the Navajo Nation Council into the Navajo language" but planned "to consult with experts in the Navajo language" so that his staff could "use it in their radio broadcasts to educate 
voters on what the referendum is all about."[81]

As the election neared, the opponents of the proposed fluency change intensified their efforts to convince voters to vote against such a change. Foremost and most articulate of these opponents was the highly respected, Peterson Zah, the Nation's very first president, who in the highly emotional message quoted in the beginning section of this paper, strongly urged them to vote against the fluency amendments.[82]

On June $16^{\text {th }}$, the Navajo Election Administration posted an official notice about the July $21^{\text {st }}$ election giving voters details about the election including the hours when the polling stations would be open at the chapter houses which would be from $6 \mathrm{AM}$ to $7 \mathrm{PM}$. Also included were a "Descriptive Summary" and a "Brief Statement of Legal Effect" that read as follows:

\section{Descriptive Summary}

The Navajo Nation Council refers to Navajo voters the question of who will decide whether candidates for the Office Of President and Vice-President speak and understand the Navajo and English languages. Navajo law at this time requires candidates for President and Vice-President to fluently speak and understand Navajo and read and write English. Also, at this time, the Navajo Election Administration determines whether candidates meet the language qualification based on candidate applications. If Navajo voters pass the Referendum by a majority vote ... This means Navajo voters will decide by their vote, whether candidates for President and Vice-President meet the language qualifications.

\section{Brief Statement of Legal Effect}

A "FOR" vote will allow Navajo voters to decide, by their vote, whether a candidate for President and for Vice-President meets the Navajo and English qualifications.

A "Against" vote is against amending the Navajo Nation Election Code on the current language requirements for Office of the President/Vice President. A "Against" vote will not amend the Navajo Nation Election Code.[83]

Opposition to passage of the Referendum intensified as the newly elected president and vice-president joined former tribal chairman and first president Peterson Zah to urge the voters to vote against this proposed change which they strongly felt threatened the very survival of not only the Navajo language but also the Navajo Nation's unique cultural heritage. And "spots" began appearing on local radio stations "contending" that approval of the change would lead to a time "when someone who knows nothing about the Navajo culture or the Navajo language will get voted in", a possibility which Steve Begay, a member of the Navajo Voters' Coalition, argued would not happen "at least in the near future" since he felt that Navajo voters would "require some level of efficiency in understanding the Navajo language and culture."[84]

Despite this intensified opposition, those supporting the change won the election by a 13,017 to $11,778(11,779)[85]$ vote on Election Day, a narrower margin of victory than first expected but nevertheless a decisive one since of all the reservation polling stations "the Chinle agency was the only agency that voted against the proposed change and that was by only a couple of hundred votes."'[86]

Hoping to help heal the bitter feelings that the opposing sides still had toward each other, Council Delegate Leonard Tsosie, one of the strongest supporters of the fluency referendum, announced that he would sponsor a bill to create a Navajo language commission that he hoped would "look at ways to work with Navajo healers to preserve language, cultural and traditional ecological knowledge." and, Council Delegate Tom Chee, "called upon the Navajo Voters Coalition to issue some sort of media announcement in an effort to comfort both sides of the language referendum issue", saying that, "Navajo is my emotional language, and English is my money language" and that there needs to be a "delicate balance" between the two.[87]

While on the "losing" side, President Russell Begaye, "instead of appointing supporters to top division spots ... began a search for the most qualified Navajos he could find, and the new division directors turned out to be graduates of Harvard and other top-ranked universities."[88]

Will the Navajo language escape the eventual extinction most other indigenous languages are now facing in the modern world? In the aftermath of the election and fluency referendum, will the new, very intensive, efforts to inspire more young Navajos to earnestly embrace their ancestral language, succeed? Only time will tell but as an exchange professor at Navajo Community College (now Diné College) at Tsaile, AZ in the fall of 1994, a young Navajo college student, almost in tears, confided to me how disturbed she was that a fellow non-Indian student was learning to speak and read Navajo much faster than she was.

And, more recently while serving 18 months as an unpaid volunteer at an employment service near Window Rock, one day at the local post office, I witnessed a Navajo woman, probably in her late $40 \mathrm{~s}$, having trouble buying stamps. It soon became obvious that she could not understand even the most common English words spoken to her by the Navajo clerk who was probably in his late 20 s who, in turn, could not understand anything she was saying in Navajo. Finally, when further communication between the two seemed hopeless, her bilingual companion (probably her husband), who was standing nearby behind her, broke the impasse.

This woman was probably from a remote part of the reservation and had spent little or no time in a classroom. The Navajo clerk on the other hand represented the large number of younger Navajos who know little or none of the language of their ancestors and have not felt that it was worth their time or effort to achieve "fluency" in it, often an extremely difficult task for those long passed their childhood years.

Further evidence for decline in fluency rates came in a 
recent announcement for a food handling training class, a necessary step in obtaining many jobs on the reservation, where it was stated "class will be conducted in English (bring interpreter if needed)."[89] Equally embarrassing for the language preservationists was the one-word Navajo blessing prayer sung by the former Arizona State senator Carlyle Begay at Donald Trump's inauguration. In defense of his brother, Benny Begay, a medicine man said that while, "I'm very proud of my brother," "his less than eloquent use of the language points out the need for elders who know the songs and prayers to make sure they pass them down to their children." "I tell my patients or my audience to speak to your kids as much as we can in the Diné language so we don't come across something like this." He then emphasized "that people may think their children have no use for Diné Bizaad ...until they do." "maybe one day they might be in a high position, just like Senator Begay." "He did the best he could. And I appreciate that. It's a wake-up call for us Diné people. Say, Hey wake up! So we don't have to see that again.’'[90]

\section{Conclusions}

For many years now those bemoaning the younger generation's diminishing Navajo "fluency" have put the primary blame on the federal government which had forced their parents and grandparents into boarding schools as well as other cultural assimilation programs such as the Republican Congress's 1950s and 1960s termination and employment relocation efforts[91] and the now discontinued Mormon Placement Program.[92] However, in the case of Chris Deschene's mother who had been forbidden to speak Navajo during her boarding school years, she deliberately "focused on teaching her son English, which she said would offer him more opportunities."[93] And during my own fieldwork on the Papago (now Tohono O'odham) reservation and nearby company town of Ajo:

Among the school children it was by now "popular" to speak English and downgrading to be caught speaking Papago or some other Indian language, and in the case of intertribal or interethnic marriage, English usually served as the 'lingua franca" between the marriage partners. Even one much older adult who had grown up on the reservation and still had strong ties to it when he heard that a white man at Sells (the tribal capitol town on the nearby reservation) was in the process of preparing materials to teach written Papago to reservation school children and adults said that it was "foolish to teach written Papago" ... and another adult added that "if you set yourself apart, then other people will consider you as different."

During my stay in Ajo, there was only one Papago husband and wife that were attempting to teach their children any of the old Papago stories, songs, dances, and skills and this in large part was being done for commercial gain since the members of this family formed a professional dance team that often performed during various social events in Ajo, on the nearby reservations, and in neighboring towns.[94]

Thus, just as these individuals and members of other reservations where few if any are "fluent" in their ancestral languages, feel that their tribal identity should never be challenged, Deschene in an appearance before the Navajo Supreme Court on September 26, 2014, insisted that he was "no less Navajo - and no less fit to lead - simply because he [had] not mastered the language [noting] that he, like others in the courtroom, had grown up riding horses and sleeping on a sheepskin on the reservation."[95]

In response, Chief Justice, Herb Yazzie, drawing "on a legend in which one of the holy people warned the Navajo never to forget the value system they had been taught," stated that "core to that value system is the language."[96] However, judging by the overwhelming coverage given to military veterans and young athletes in the Navajo Times, the accomplishments of these modern "warrior leaders" such as Deschene could be argued as being even more important than language to the continued survival of a Navajo "value system"[97] which like "fluency" is subject to many different interpretations and has changed significantly through time after the arrival of new animals (e.g., horses, sheep), new plants (e.g., corn, peaches), new craft skills (e.g., weaving, jewelry making) and new rituals (e.g., Pueblo, Catholic, Mormon, peyote).

Given the ability to make such structural or behavioral modifications as needed to survive environmental change has long been exhibited by the Navajo people even though it has resulted in many young individuals not feeling that choosing English over Navajo as their primary language makes them "less Navajo" then their more fluent elders. In fact, the rising political strength of the Navajo Nation, although I attributed it primarily to its extremely high birth rate in my 1971 Human Organization article,[98] has also been greatly enhanced by the eagerness of its young people to seek new ideas and skills from the outside world through education, following the advice of the revered war leader Chief Manuelito.

As expected, exposure to the outside educational experience has often caused young Navajos to modify their interpretation of Navajo origin stories when confronted with scientific evidence to the contrary but this does not always shake their faith in the power of medicine man and ceremonies to cure their physical and psychological troubles.[99] For such individuals these ceremonies are the core concepts of the Navajo value system which are now threatened as fewer young people speak and understand Navajo. Thus, Harry Walters, the director of the museum at Navajo Community College during the time I was an exchange professor there, stated in the draft of a book he was writing that an examination of early Navajo stories:

... illustrates that the Navajo once lived in a 
hunter-gatherer patrilineal society" but with the coming of agriculture [Navajo society] ... evolved into a matrilineal society." This transition was finalized with the coming of a ceremonial known as the "Blessing Way." Today, Blessing Way is the backbone of Navajo Ceremonialism and society.[100]

Harry, despite his extensive off reservation training in anthropology has not lost his Navajo fluency nor his belief in the historically evolved version of Navajo ceremonialism. This was clearly seen when he led that fall's new 1994 instructors, including me as an exchange professor, to the mountain in New Mexico where it was believed that the extremely important deity, "Changing Woman," first appeared and he there cast an offering of corn pollen to the east followed by a fluent Navajo Prayer.

In my 2009 comparative historical analysis of "human-created systems" in the American Southwest, it became obvious that just as few natural species have withstood the test of ever-changing earth environments through time, relatively few companies, religions, governments, etc. long survive their creation and that the most long lasting of those "systems" owed their long-term survival to what can be labeled "ultra-adaptability" (i.e., "the capacity to persist in time through structural or behavioral modification" to avoid or survive one or more of what Gladwin has called "tipping points.").[101] Navajo ceremonies have fully exhibited such a capacity, a prime example being the following:

Enemy Way has never died out among The People. Most of the other war ceremonials had practically gone out of use before World War II, but since 1941 a number of them have been revived. It is interesting to note certain strange combinations of old Navajo war ceremonials with bits of other rites and even elements of Christian practice.

These revived and combined rites were used to assure the safety of Navajo men in the armed forces. One such ceremonial was filled in May 1944 for the well-being of 150 servicemen, Navajos working in war industries, and members of the Allied armies. Before the ritual began, photographs of the servicemen for whom the ceremonial was held were piled up in front of the "medicine man." This man, a famous Singer, sang ancient war songs, and Christian Navajos were encouraged to add their prayers to the tribal chants. After the all-night ritual, prayer feathers adorned with turquoise were planted to help assure the warriors' safe return.[102]

Especially controversial In trying to obtain a consensus about what are the "true" elements of the Navajo value system is the belief by reservation converts to Mormonism that joining the church has brought them closer to the fundamental Navajo values of family, charity, camaraderie and respect for the land. And as one of them, Nora Kaibetoney, explained in Navajo through a translator to a
New York Times reporter, even though Mormonism often compels them to leave behind rituals that have long defined their identity, (like a medicine man's healing ceremonies or the cleansing in sweat lodges)[103], there is a feeling of "reconnecting to our traditions." [104] Also, the daughter of a Navajo code talker and hand trembler (a traditional diagnostician), told the same New York Times reporter, that converting to Mormonism as a high school student, "wasn't about turning away and embracing an entirely different tradition: it was about reconnecting."[105] And further distancing themselves from Christian denominations who also, like Mormons, discourage seeking help from "medicine men," Navajo members are told that they are descendants of Israelites whose forefathers through disobedience had lost the true knowledge of their past but who would now play a key role in the events leading to the second coming of Jesus Christ.

However, paradoxically, rejection of healing and other traditional "medicine man" ceremonies does not mean that Mormons have no interest in the preservation of the Navajo language.[106] In fact just the opposite is demonstrated by certain members' heavy involvement in the recent production of Navajo language versions not only the LDS "sacred"[107] temple rituals but also of "Star Wars" and "Finding Nemo." Also, the Church's extreme emphasis on searching out as much information as possible on deceased ancestors so that temple ordinances can be performed to ensure their dead ancestors' salvation in the afterlife and to be able to be reunited with them again there, encourages members to learn enough Navajo to be able to read old records, conduct interviews with non-English-speaking elderly people and converse with dead loved ones in the afterlife.

This embrace of maintaining contact with the dead is in sharp contrast to the still strong fear of the dead by most Navajos.[108] Thus, whenever there was a traffic accident during the time I spent running the employment center, a Mormon tribal policeman that I knew, was always dispatched to the scene to retrieve and dispose of dead people or body parts that the other officers refused to touch. And earlier during my time as an exchange professor at the Navajo Community College, many staff members feared entering the main building at night, believing it was haunted by spirits of the dead. In fact a rumor was being spread that the building had been built on the graveyard of Navajos that had been killed during an encounter with the U.S. military.[109]

A far greater danger to the long-term survival of the Navajo language was pointed out by Linda Gerber in her 2010 peer review of the author's 2009 book in the American Indian Culture and Research Journal where, in summarizing the work of the Canadian sociologist, Raymond Breton, she states that:

... boundary maintenance is most successful when an ethnic group ... has the organizational complexity to meet all or most of the needs of its members within its 
own boundaries. Communities that are sufficiently large and well organized enough to have their own places of worship, credit unions, specialized retail outlets, restaurants, social services, real estate agencies, and employment opportunities will be able to retain their members more effectively - even over generations. Thus, institutional completeness, which refers to the kinds of mechanisms of environmental control identified by Stucki, is a powerful determinant of long-term viability or survival.[110]

Here then is the greatest threat to the long-term survival of a distinct Navajo "value system" and daily language use when the most recently released unemployment figure on the reservation is $44.25 \%$ [111] despite large numbers of unfilled hospital, law enforcement, and other professional positions and where most shopping is done off-reservation.[112] Nor do the continued high rates of alcoholism, domestic violence, teen-age pregnancies, theft, government corruption, etc. meet the perceived societal needs of those living on the reservation.[113] Ironically, the very Navajos who could take the lead in solving such problems while ensuring the long-term viability of a Navajo "value system" are the often rejected, younger, highly educated, highly skilled Navajos whose only perceived flaw is insufficient Navajo language "fluency." However, even though Chris Deschene and his many supporters appear to have "lost" this first round in the ongoing battle to overthrow this rejection, the passage of the amended presidential fluency requirement may in the future be viewed as a crucial "tipping point" in this continuing struggle.

Perhaps the question that should now really be asked is not "dying language, dying culture?" but rather "dying culture, dying language?" since the poor employment and living conditions on the reservation do much to force people to increase their interaction with the surrounding outside English-speaking world. Thus it can be argued that any remaining hope that Navajo will survive as a living daily language will require the solution of the myriad problems facing reservation residents.

Solutions to the problems standing in the way of achieving "institutional completeness" will not be easy since almost any suggested social, economic, or political change will have its foes. Especially hard to solve will be those which are a result of the reservation system and the unique powers and privileges given to or taken away from tribes by Congress. For example, although enrolled Navajos have universal government-paid healthcare coverage, on-reservation hospitals are woefully understaffed despite strong attempts to recruit and retain outside doctors, nurses, dentists, etc. who often find life on the reservation too challenging, especially if they have school-age children.[114] Thus many Navajos must be transported to off-reservation medical facilities for treatment.[115]

And effective crime control has been made difficult starting with the passage of the 1885 major crimes act that took away the power of tribes to independently arrest and prosecute criminals committing such crimes as assault, rape, and murder.[116] Instead, jurisdiction over these offenses was given to the FBI or other off-reservation law enforcement agents and courts who often with great reluctance have accepted this extremely difficult task where such things as witness intimidation make successful prosecution difficult. As a wife of an FBI agent told the author in a Gallup grocery store one day, the transfer of her husband to the nearby reservation was "like him being sent to Siberia."[117] In recent years the federal government has tried to create a working relationship between the FBI and tribal policeman but as one tribal policeman complained to me, "they want us to do all the investigative work but then they take all the credit if the crime is solved."

During my fall 1994 semester at the Navajo Community College, crime by juveniles was completely out of control. Not only were faculty houses being vandalized when not occupied but even the house of the college president had been broken into three times. Also, visitors to the lookout points on the nearby North rim of Canyon DeChelly were greeted by severe warning signs to leave nothing visible in their vehicles during the brief time it would take to walk to and return from the viewpoints. Even though the police knew who these young vandals were, the new juvenile detention center not yet been completed so no arrests could be made. Making things even worse was a lawsuit by the American Civil Liberties Union that had closed the tribal jails because of overcrowding. Thus, even the limited ability of tribal policeman to lock up individuals for minor crimes such as shoplifting, theft, or burglary for a maximum of one year did not exist during this period of time. Although upon my return in the fall of 2013, some of the earlier problems had been solved, I was told by a law enforcement recruiter of the severe problem he had been having in recruiting young Navajos to fill the dozens of unfilled law enforcement positions. He complained that most of the individuals he interviewed either failed to pass the physical requirements or were disqualified because of crimes committed as juveniles.

This severe hindrance in achieving institutional completeness is well demonstrated in the following excerpt from a 2016 article by Bill Donovan:

The Navajo nation, in 2014, reported 489 violent crimes with three murders and 316 rapes, according to the FBI figures.

The reservation usually averages between seven and 11 murders a year and the 2013 figures supplied by the Navajo Nation showed a total of 389 rapes for the year.

That's more rapes than cities like Phoenix, Detroit and Atlanta reported for the year.

Talking about rapes on the reservation, the biggest problem continues to be the lack of prosecution. According to Navajo figures for 2013, less than 10 of those 389 cases ended up with the suspect being prosecuted by the U.S. Attorney's office. [118]

An equally important critical problem preventing the Navajo Nation from achieving a state of "institutional 
completeness" is that of an extreme shortage of on-reservation employment opportunities. Thus, the many attempts to entice major corporations to locate manufacturing or other facilities on the reservation, although sometimes initially succeeding, have had a long history of failure. Especially damaging to this recruitment effort was the Navajo Nation's ineffective handling of the 1975 AIM (American Indian Movement) takeover of the Fairchild semi conductor plant.[119] Other difficulties stem from the reluctance of families that have long held grazing rights to land on the reservation to accept any reduction in acreage and the fear that a company would not have complete control over the hiring and firing of Navajo workers.[120]

Long gone are the days when most Navajos earned a living from the herding of sheep and cattle and even those families still relying on herding for a living face the major problem of vastly overgrazed land made much worse by the enormously out of control wild horse population.[121] And employment in the energy extracting industry, long an employment option for unskilled labor, is facing a continuing decline despite the promises given by our current president, Donald Trump. Any attempt to revive the mining of uranium brings back bitter memories of lasting health damage to former miners and their families. And efforts by tribal leaders to save the jobs of coal mine workers and those employed at the coal-fired electric power plant on the shores of Lake Powell seemed doomed since the electricity it produces is no longer cost competitive to power produced by plants fueled by natural gas.

Using tribal financing, the Navajo Nation now owns 14 enterprises and corporations that in 2015 "collectively employed 4,500 people and generated 950 million in revenue" but only a small fraction of this revenue is actually returned to the tribal treasury "to benefit all members of the tribe."[122] Although the Navajo Nation, like other tribes, does not release any information about casino revenues or profits, the Navajo Nation Gaming Enterprise joined by the Navajo Engineering and Construction Authority are the only two of the 14 that have paid back money to the tribal treasury[123] but the newest, most elaborate casino, Twin Arrows, near Flagstaff "continues to struggle because of the more than $\$ 200$ million it owes to the tribe for the cost of constructing the casino and resort hotel."'[124]

Will the stepped up efforts by the current tribal administration to use tribal financing to promote on-reservation business growth succeed better than similar efforts by past administrations? Only time will tell but with falling revenues from resource extraction and cutbacks in spending proposed by the current occupant of the White House, the success of such efforts is currently not very promising.

Somewhat more promising are continuing efforts to use tribal funds to purchase commercial property off the reservation, not with the purpose of it being transformed "into trust," (i.e., the land would not become part of the reservation) but as income-producing investments, the latest of which is the decision to purchase a very scenic 16,379 acre ranch in an area on which the Navajos once lived in south-central Colorado.[125]

Large numbers of Navajos coming to our employment center during the election turmoil were seeking to obtain employment with the tribe but after filling out and submitting numerous application forms, were only extremely rarely invited to actual job interviews. This was especially frustrating to those young Navajos who fully met the educational and skill requirements of the advertised position. This seemed to validate the commonly held belief of job-seeking Navajos that it was not "how much you knew but who you knew" if you wanted to obtain tribal employment. Compounding this problem was the tribe's long-standing decision to equate two years of prior tribal employment to the attainment of an associate level degree, four years to a bachelor's degree, and six years to a Masters degree. (It was only near the time of our departure from the reservation that the director of the tribal human resources department told me that this equivalence would no longer be honored, a change that had met considerable opposition from many long-term tribal employees.)

The employment situation for those single mothers and other high school dropouts was especially dismal. Even though there were large numbers of low-wage, unskilled motel jobs in the closest off-reservation city, Gallup, New Mexico, lack of dependable and affordable transportation to and from there discouraged almost all from even applying for such vacancies.[126]

Many Navajos earn some income from the creation of rugs, pottery, etc. for sales to visiting tourists and non-Navajos living on the reservation while others are paid by relatives or friends to repair things or provide other services. Still others specialize in making and selling Navajo tacos or other food items. And often overlooked in official employment statistics is the income singers ("medicine men") derive from traditional ceremonies.[127]

However, more ambitious entrepreneurs face the problem of obtaining operating capital to establish or expand on-reservation businesses since few such individuals have assets that can be seized by banks if loans are not repaid.[128] And even those few Navajos who have such seizable off-reservation assets are taking great risks in trying to create employment opportunities at locations on the reservation.[129] Fortunately, one such individual, Romero Brown, has apparently succeeded.[130] In his case he had wisely bought enough non-reservation land at St. Michael's that had previously been a part of the Catholic Church's large acreage that, although completely encircled by the reservation, had never been part of the reservation. With this now seizable asset he was able to obtain loans to not only to build his house but also the NavajoLand Inn \& Suites and a very successful Denny's restaurant. Why then would he take the terrible risk of trying to open a new Denny's restaurant possibly followed by another motel at Chinle Arizona on tribal land since after obtaining loans including a large one 
from the tribe, he was facing local opposition and if final tribal approval for the project was not soon granted, would risk losing not only his St. Michael's Denny's restaurant and the NavajoLand motel but possibly also his house? Why then take this extremely risky gamble? He told me that as the top local LDS (Mormon) church leader (Stake President) of most members in Arizona east of the Hopi reservation, he felt a strong obligation to provide employment opportunities for church members and others in Chinle, an area of very high unemployment.[131]

On the tribal level, a new attempt to reach the goal of "institutional completeness" has been proposed by the new Navajo Nation President, Russell Begaye, who after signing into law the Nataani Development Corporation, a new holding company incorporated under Section 17 of the Indian Reorganization Act, predicted that within at least three years this would be the solution to end the $47 \%$ unemployment rate on the Navajo Nation. This "private-sector vehicle" would focus on "job creating economic projects and generating revenue for the Nation by way of sharing dividends with the General Fund and Permanent Trust Fund." Key to his optimism that this new corporation would be able to attract job-producing companies to the reservation is that they would receive federal tax exemption. Thus, he further predicted that this would "help the Navajo Nation be one of the largest employers in the Southwest."[132]

Not waiting to see if this enticement succeeds in bringing in new "job producing" companies, the Tribal Utility Authority is: "launching its Renewable Energy Program with the goal of powering the Navajo Nation with wind and solar projects," starting with a \$60 million solar project at Kayenta making it "the first among all Native Nations to develop a utility scale solar farm."'[133] Again, as in many past years, the "ultra-adaptability" of the Navajo people is demonstrated as they realize that their economic security can not forever continue to be based upon the extraction of coal and oil from their lands.[134]

However, an attempt to emulate the economic success enjoyed by the Hualapai tribe when they allowed the construction of their world-famous skywalk in the Grand Canyon[135], a proposed Navajo tramway to transport tourists from the rim of the canyon to the confluence of the Little Colorado River with the Colorado River has met with fierce opposition from many outside special interest groups[136] and bitterly divided Navajos.

Thus, in a Letter to the Editor of the Navajo Times, a 63-year-old grandmother strongly pleads with those Navajos, especially their leaders including Navajo Nation President Russell Begaye[137], to drop their opposition to the project in the following words:

We, as grandparents, are going into our golden ages and we would like to plant a seed for our kids as we go into the dawn of our age. Every other year we lose elders along with the stories and the ceremonies they hold. We are seriously losing our culture, our language, and our way of life but if our children come back to our homeland we will find a way to sustain them.

... I live by myself. All my children and grandchildren live in other states. I want my children and grandchildren to come home to me ... I want them to have opportunities at a job where they can go to work in the morning and come home every evening....

Nowadays, very few people have livestock and their livestock are limited. Our grazing grounds are depleted around the Grand Canyon project area. Every family that I know, their livestock are diminishing, especially the sheep and goats. To the people who oppose to the project, I ask in my mind, have they ever had any sacred corn pollen blessing, or know basic knowledge of the many areas of Navajo traditional ceremonies?

I asked this question because I don't see the opposition living among us in the Bodaway Gap Chapter, none....

We are tired of government handouts; it does not help us emotionally and spiritually. Our forefathers never asked for handouts from the chapter or our government in Window Rock. Why should we do that now?

We as a community at Bodaway Gap Chapter would love to see something great built to help sustain ourselves and to not continually rely on government handouts.[138]

And in another more recent letter to the editor another Bodaway/Gap elder Harley Johnson said, "I think of the children, future, that is why I support (Escalade). We have to come together with the non-Natives, just like the confluence."'[139] The letter writer then goes on to state:

Building the Escalade will bring people together from all over the world to enjoy the Grand Canyon, hear Navajo stories, learn about Navajo culture, and in exchange provide 3,500 Navajos with paychecks to sustain their families and culture.[140]

Having been involved personally in a similar dispute about a proposed tramway from the rim of the Grand Canyon to the spectacular waterfalls of Havasu Creek just downstream from the village of Supai, I witnessed the extremely effective opposition to such a project coming from powerful outside interests. They in turn were also joined by those local tribal members who controlled and earned their livelihood from the pack animals that brought mail, groceries, and tourists down the long trail from the canyon rim to the village.[141]

Today, in making a final decision about the Escalade proposal, Navajo leaders face even greater pressure from outside interests than in the past. Thus in addition to the expected opposition from the Hopi tribe which views the confluence of the two rivers as an especially sacred site, river runners and wilderness preservation groups having lost such battles as the one to save Glen Canyon from the dam that destroyed much of its beauty and archaeological treasures, have also joined the opposition to the project. 
And, even when these same wilderness groups have supported the Navajos, other tribes, and the tourist industry in the fight they all are now waging against the oil, coal, and gas lobbies in defense of the Bears Ears Monument in Utah, they now face the formidable wrath of local non-Indians, all state and federally elected officials in Utah, and the Trump administration. Compounding the problem for the Navajos in the flight to preserve the Bears Ears Monument is that although they outnumber non-Navajos in San Juan County, Utah (the county containing this monument), the non-Navajos by gerrymandering voting districts still hold almost complete political control of the county.[142]

This brings up a final major problem facing Navajo leaders as they try to create the necessary "institutional completeness," the problem of having to deal with political leaders in three states, Arizona, New Mexico, and Utah as well as federal bureaucrats and politicians. One possible solution to this problem was discussed in an interview (arranged by the Nation's human services director) I had with the Vice President of the Navajo Nation in 2014 just prior to the fall election that year. After discussing the problems that the Navajos coming to our employment center were having finding employment, he and I both agreed that an earlier suggestion made by certain tribal leaders and me[143] that pursuing the possibility of the Navajo Nation becoming the 51 st state in the United States might do much to increase the political and economic power of the tribe. However, he felt that by so doing they would have to allow non-Navajos the freedom to have equal access to such things as land ownership, voting rights, employment, political office, etc. This he felt would be too great a price to pay even though it could do much to further the goal of "institutional completeness."

Hostility continues to exist between the Navajos and their border town neighbors as exhibited in such places as Apache County, Arizona which when established was controlled politically by the non-Indians living south of Interstate 40 . Now, however, as non-Indian youngsters have left the rural small towns to obtain employment in Phoenix and other large cities, Navajos have gained political control of the county which has caused deep resentment on the part of white residents in the towns south of the interstate whenever their tax money is being used to support services or projects on the reservation "because the Navajo nation does not pay taxes for their services."[144] Thus, since losing control of the county to the Navajos, attempts have been made by those living south of the interstate to split the county, the latest of which is Arizona House Bill 2040 that would:

...divide Apache County at the interstate highway. Everything south of I-40, where the county is mostly white would become part of Greenlee County and everything north - where the county overlaps the Navajo nation - would be the new Apache County.[145]
This hostility toward the Navajos and other tribes is especially exhibited by the current attempt by local and national Utah politicians led by Senator Orrin Hatch and Representative Rob Bishop who have put tremendous pressure on the Trump administration to eliminate or downsize the newly created Bears Ears National Monument. Now with the vindictive recommendation by Interior Secretary Ryan Zinke to shrink the monument from 1.35 million acres to a mere 160,000 acres[146], the five tribes that had sought the creation of the monument are now prepared to go to court to prevent President Trump from caring out the wishes of Utah's elected leaders.[147]

This disregard for the wishes and welfare of the Navajos was also seen years earlier when I made a proposal to Utah State officials to consider cooperating with the Navajo Nation and the state of Arizona on the possibility of extending I-17 northward from Flagstaff to I-15 in southern Utah or to Salt Lake City by way of US 89, US 160, US 191, and US 6. This not only had the potential of providing thousands of employment possibilities for Navajos but would also have made the heavily traveled and extremely dangerous road from Green River, Utah to Spanish Fork, Utah much safer. Although gaining some interest from the staff members of Senator John McCain, the Navajo Nation, and certain local town leaders especially in Price, Utah, it was rejected by state officials in Utah who had no interest in helping improve the quality of roads in Arizona or even on lands in Utah that were part of the Navajo Reservation. In fact in a letter from the Utah Department of Transportation, they told me that they were already planning new upgrades to the existing roads in Utah that were in my proposal except for the stretch of highway passing through the Navajo reservation from the Utah border to the San Juan River which upgrade apparently was not even being considered at that time as being important.

Facing such opposition is a major challenge for Navajo leaders both elected and appointed who must also take into account the rising expectations of their constituents no longer isolated from the off-reservation world through the military, off-reservation employment, the relocation program, the Mormon placement program, etc. Navajos having once been exposed to such things as indoor plumbing and electricity as well as better roads, housing, educational, and employment possibilities, put tremendous pressure on their leaders to provide such amenities or face forced removal from office or defeat in a following election. For those still hoping to stem the declining use of Navajo as the primary language spoken in the home, the failure of these leaders to meet these "institutional completeness" expectations would be an especially ominous sign. However, the remarkable "ultra-adaptability" exhibited by Navajos, both individually and collectively, in meeting past life-altering challenges still offers such Navajo language preservationists a "ray of hope." 


\section{REFERENCE}

[1] Ian Lovett, "Presidential Candidate in Navajo Nation Protests a Language Requirement," The New York Times, September 26, 2014.

[2] John McWhorter, "The Power of Babel: A Natural History of Language," (New York, Harper Collins 2003 Perennial edition of hardcover book published in 2001 by Times Book), 272.

[3] ibid., 258.

[4] Bill Donovan, "Times tries its hand at teaching Navajo," 50 Years Ago Column, Navajo Times, December 8, 2016, A6.

[5] ibid.

[6] A series of faculty and staff meetings occurring during the author's time as an exchange professor at Navajo Community College, fall semester 1994.

[7] Staff reporter, "NNBOE approves study of new assessment," Navajo Times, December 15, 2016, C7.

[8] Colleen Keane, "Diné language gathering calls for nationwide effort," April 6, 2017, A2.

[9] ibid.

[10] ibid.

[11] John McWhorter, "The Power of Babel: A Natural History of Language," 267. After I presented the original version of this paper at the annual meeting of the Society for Applied Anthropology in Vancouver, BC in 2016, a Navajo probably in his 30s approached me and said that his parents had been very critical of the Navajo dialect that had been taught him in school.

[12] Although not all anthropologists continue to favor this hypothesis, many still do and are often key supporters in the fight to reverse the decline in native-language fluency occurring in younger generations. One of the strongest attacks against this hypothesis is found in John H. McWhorters' book, "The Language Hoax," (Oxford University Press, 2014).

[13] Peterson Zah, "Preserve the Navajo language, vote against the fluency amendments for referendum," Navajo Times, July 16, 2015, A7.

[14] A reviewer of an earlier draft of this paper recommended that I remove any first person references not realizing that my analysis of the events occurring during this time period would have been quite shallow if my participant/observation findings could not be included. Participant/observation is a time honored method used by trained anthropologists to gain a more complete understanding of events beyond that contained in published reports, books, newspapers, etc. My involvement with the Navajos began with a class assignment at the University of Colorado in 1966 to go to the bars in downtown Denver to study Navajo language drinking terminology. After laughing themselves silly that the University of Colorado would send a non-drinking student to attempt such a task, the five Navajos I met there happily supplied me with enough information to create a class paper (unpublished but available from the author upon request). This was followed in 1969 with involvement in a study to measure the effectiveness of healthcare delivery to low income individuals in the Denver area including many
Navajos who were living there as a result of the government's relocation program. And in 1994, a colleague, Susan Hartman, and I established a working faculty and information exchange relationship between Reading Area Community College (RACC) and Navajo Community College (now called Diné College) as well as a new honors "Navajo Studies" course at RACC. (Prior to this, many other well respected universities and colleges had tried without success to establish such relationships.) While there at Navajo Community College, as half of my teaching load, I was the facilitator for weekly special curriculum development sessions for the Navajo Studies instructors (at their request) as they revised individual syllabi and eliminated gaps and duplication in the overall program prior to an upcoming accreditation visit.

[15] Ralph U. Davis, "Gov't not designed to meet needs of people," Navajo Times, January 16, 2014, A6.

[16] Alysa Landry, "Navajo Corruption Case Winds Down," Indian Country Today, March 2, 2016, 7.

[17] ibid.

[18] Karletta Chief, "New leadership does exist," Navajo Times, February 20, 2014, A6.

[19] ibid.

[20] Gary Bernally, "Old guard vs. nation builders," Navajo Times, July 17, 2014, A7.

[21] Ian Lovett, "Presidential Candidate in Navajo Nation Protests a Language Requirement," The New York Times, September $26,2014$.

[22] The 2014 Navajo Board of Election Supervisors, "The 2014 NBOES Speaks Out," Navajo Times, March 12, 2015, A11.

[23] Cindy Yurth, "Supreme Court to hear Deschene case," Navajo Times, September 18, 2014, A1,3.

[24] Bill Donovan, "Election may be postponed due to Deschene challenge," Navajo Times, September 25, 2014, A1,3.

[25] Krista Allen, "Deschene to face OHA Oct. 3," Navajo Times, October 2, 2014, A1,2.

[26] Alastair Lee Bitsoi, "Election Board votes to move forward with Nov. 4 election," Navajo Times, October 2, 2014, A1,3.

[27] Bill Donovan, "High court: Fluency a 'reasonable regulation' of a candidate," Navajo Times, October 9, 2014, A1,3.

[28] Pauletta White, "The people have voted for Deschene," Navajo Times, October 2, 2014, A6.

[29] Eunice Annazbah Muskett, "Fluent, the word that destroyed our democratic process," Navajo Times, December 31, 2014, A6.

[30] Harvey Begay, "History says English is a requirement," Navajo Times, October 16, 2014, A7.

[31] The 2014 Navajo Board of Election Supervisors, "The 2014 NBOES Speaks Out.” Navajo Times, March 12, 2015, A11.

[32] ibid.

[33] Krista Allen, "Justice is let the people decide," Navajo Times, November 6, 2014, A4; Donovan Quintero (Times photos), "Rights as voters," Navajo Times, November 8, 2014, A8.

[34] Alistair Lee Bitsoi, "Delegates circulate $2^{\text {nd }}$ petition for special 
session to amend language requirement," Navajo Times, November 6, 2014, A1,3; Cindy Yurth, "Big winners are the lawyers in 2014 election," Navajo Times, November 6, 2014, A9.

[35] Bill Donovan, "High court disqualifies 2 Council candidates," Navajo Times, November 6, 2014, A10.

[36] Cindy Yurth, "Prez election still hot topic at chapters," Navajo Times, November 6, 2014, A10.

[37] Cindy Yurth, "Big winners are the lawyers in 2014 election," Navajo Times, November 6, 2014, A9.

[38] Bill Donovan, "New date for presidential election set for Dec. 23," Navajo Times, November 6, 2014, A1,3.

[39] Alistair Lee Bitsoi, "Delegates circulate $2^{\text {nd }}$ petition for special session to amend language requirement," Navajo Times, November 6, 2014, A1,3.

[40] Cindy Yurth, "Big winners are the lawyers in 2014 election." Navajo Times, November 6, 2014, A9.

[41] Bill Donovan, "Another big day for Navajo Nation Election," Navajo Times, November 13, 2014, A1,3.

[42] Bill Donovan, Election for president postponed to 2015," Navajo Times, November 20, 2014, A2.

[43] Bill Donovan, "Begaye wins decision over his qualifications," Navajo Times, November 26, 2014, A1,3.

[44] Paul Natonabah (Times photos), "March to address treatment of former prez candidate," Navajo Times, December 4, 2014, A7.

[45] Bill Donovan, "Begaye's court fight delays new election date," Navajo Times, December 4, 2014, A1,3.

[46] Bill Donovan and Alistair Lee Bitsoi, "Funds for special election are now the issue," Navajo Times, December 24, 2014, A5.

[47] ibid.

[48] Arlyssa Becenti, "Who will be president?," Gallup Independent, December 27-28, 2014, 1,5.

[49] Arlyssa Becenti, "Deschene files for reinstatement," Gallup Independent, December 31, 2014, 1,5.

[50] Bill Donovan, "Council sets new dates for presidential election," Navajo Times, January 8, 2015, A1,7; Kathy Helms, "Bill for NN elections passes," Gallup Independent, 2 January $2,2015,1,5$.

[51] Alastair Lee Bitsoi, "President says Navajo people should decide on language fluency issue," Navajo Times, January 8 , 2015, A7.

[52] Arlyssa Becenti, "Council pardons election supervisors," Gallup Independent, January 2, 2015, 1,5.

[53] Kathy Helms, "Bill for NN elections passes." Gallup Independent, January 2, 2015, 1,5.

[54] Bill Donovan, "No ruling from the Supreme Court about the special presidential election," Navajo Times, February 19, 2015, A1,2; Lester Begay, "Tsosie, Bates needs to be removed," Navajo Times, April 23, 2015, A7.
[55] Bill Donovan, "Supreme Court sets up dates to hear new election complaint," Navajo Times, January 22, 2015, A1,3.

[56] Alastair Lee Bitsoi, "Council to consider bills for special presidential election," Navajo Times, January 22, 2015, A1,3.

[57] Arlyssa Becenti, "Navajo Council opts out of election discussion," Gallup Independent, February 6, 2015, 1,5.

[58] Bill Donovan, "Election office waiting for ruling by Supreme Court on election issue," Navajo Times, February 5, 2015, $\mathrm{A} 1,3$.

[59] Bill Donovan, "Shirley fights for early election," Navajo Times, February 5, 2015, A1,2.

[60] Bill Donovan, "No ruling from the Supreme Court about the special presidential election." Navajo Times, February 19, 2015, A1,2

[61] Alastair Lee Bitsoi, "Voters' rights group protests court decision," Navajo Times, February 26, 2015, A1,3.

[62] ibid.

[63] ibid.

[64] Alastair Lee Bitsoi, Group threatening recall if funds approved for April 21 election," Navajo Times, March 5, 2015, A1,2.

[65] Stacy Thacker (Times photos), "April 21 election still up in the air," Navajo Times, March 19, 2015, A1.

[66] Alastair Lee Bitsoi and Shondiin Silversmith, "Council passes election legislation with referendum on fluency," Navajo Times, March 19, 2015, A3.

[67] Bill Donovan, "April 21 election still up in the air," Navajo Times, March 19, 2015, A1,3; Katherine Locke, "Supreme Court: election must proceed April 21," Navajo-Hopi Observer, March 25, 2015, 1,7.

[68] Katherine Locke, "Supreme Court: election must proceed April 21."; Bill Donovan, "Early voting begins today in presidential election," Navajo Times, March 26, 2015, A1,2.

[69] The 2014 Navajo Board of Election Supervisors, "The 2014 NBOES Speaks Out Navajo Times, March 12, 2015, A11;" Bill Donovan, "50 Chapters pass resolutions to oust Chief Justice," Navajo Times, 26 March 2015, A1,2; Delegate Leonard Tsosie, "Chief Justice cannot do what he wants, interpret laws to his convenience," Navajo Times, March 26, 2015, A7.

[70] Delegate Leonard Tsosie, "Chief Justice cannot do what he wants, interpret laws to his convenience." Navajo Times, March 26, 2015, A7.

[71] Bill Donovan, "Preparations in place to hold presidential election on Tuesday," Navajo Times, April 16, 2015, A1; Bill Donovan, "Last-minute plot twists define election," Navajo Times, April 23, 2015, A2.

[72] Bill Donovan, "Last-minute plot twists define election." Navajo Times, April 23, 2015, A2.

[73] ibid.

[74] ibid.

[75] Felicia Fonseca, "Tribal businessman upsets former Navajo president in election," Salt Lake Tribune, April 23, 2015, A3. 
[76] ibid.

[77] Bill Donovan, "Young Diné selected for key posts in Begaye-Nez administration," Navajo Times, May 14, 2015, A1.

[78] Alastair Lee Bitsoi, "Law and Order recommends removal of Chief Justice," Navajo Times, May 7, 2015, A3.

[79] Bill Donovan, "Chief justice announces retirement," Navajo Times, May 14, 2015, A2.

[80] Bill Donovan, "Navajo fluency issue now to go to voters on July 21," Navajo Times, June 4, 2015, A1,9.

[81] Bill Donovan, "Election office has language problem in preparing for upcoming fluency election," Navajo Times, June 11, 2015, A1,11.

[82] Peterson Zah, "Preserve the Navajo language, vote against the fluency amendments for referendum," Navajo Times, July 16, 2015, A7.

[83] Navajo Election Administration, “An Official Notice," Navajo Times, July 16, 2015, A12.

[84] Bill Donovan, "New law allows Diné voters - not the courts to decide language fluency," Navajo Times, July 23, 2015, A1,11.

[85] Alastair Lee Bitsoi, "Tsosie to sponsor Navajo Language commission," Navajo Times, July 23, 2015, A11.

[86] Bill Donovan, "New law allows Diné voters - not the courts to decide language fluency." Navajo Times, July 23, 2015, A1,11.

[87] Alastair Lee Bitsoi, "Tsosie to sponsor Navajo Language commission," Navajo Times, July 23, 2015, A11.

[88] Bill Donovan, "Begaye brings changes in first months in office," Navajo Times, December 30, 2015, A1,10.

[89] "Food handler training class," an announcement appearing in the Navajo Times, April 6, 2017, A2

[90] Cindy Yurth \& Donovan Quintero, Carlyle Begay praised, lambasted for one-word prayer, Navajo Times January 26, 2017, A1.

[91] The often disastrous results of these attempts by Congress "to get the government out of the Indian business" through termination are well documented in the Report of the Commission on the Rights, Liberties, and Responsibilities of the American Indian (William A. Brophy and Sophie D. Aberly, University of Oklahoma Press, 1966). Especially tragic are the three specific examples of what happened to the Utah Paiutes, the Klamath, and the Menominee (see pages $193-207)$.

[92] Thousands of Navajo parents eager to provide better educational opportunities for their children agreed to have their boys and girls, eight years or older, be baptized into the Mormon Church and spend each school year living with Mormon families in distant cities where they would attend the same schools that the Mormon families' own children attended. Then at the end of the school year, the children would return to their own families on the reservation where the hope of church leaders was that they would then be instrumental in the conversion of their parents and friends to the message of the church, a hope that seldom was realized.
See the book Making Lamanites, by Matthew Garrett, (The University of Utah Press, 2016), for a good overview of this controversial program and its successes and failures. And for a Native American viewpoint of the program see Alysa Landry, "Assimilation Tool or a Blessing? The Mormon Indian Student Placement Program, Indian Country Today, January 7, 2016, and Alysa Landry, "How Mormons Assimilated Native Children," Indian Country Today, August 24, 2017.

[93] Ian Lovett, "Presidential Candidate in Navajo Nation Protests a Language Requirement." The New York Times, September 26, 2014.

[94] Larry R. Stucki, “Copper Mines, Company Towns, Indians, Mexicans, Mormons, Masons, Jews, Muslims, Gays, Wombs, McDonalds, and the March of Dimes: "Survival of the Fittest" in and far beyond the Deserts of Arizona, New Mexico, and Utah," (Victoria, BC: Trafford Publishing, 2009), 44-45.

[95] Ian Lovett, "Presidential Candidate in Navajo Nation Protests a Language Requirement" The New York Times, September $26,2014$.

[96] ibid.

[97] Even though the use of the Diné language by the relatively few "Code Talkers" that played a crucial role in the defeat of the Japanese during World War II on the surface seems to support the argument of the Navajo language preservationists, the extremely high rate of enlistment in the military by the younger generation of Navajo men since then does much to speed the decline of Navajo fluency as it no longer serves any purpose when communicating with the non-Navajo's in their military units.

[98] Larry R. Stucki, "The Case Against Population Control: The Probable Creation of the First American Indian State," Human Organization 30, no. 4 (Winter 1971): 393-399.

[99] This in many ways is an identical experience most Christians face when confronted with scientific evidence that seems to contradict the origin stories of the human race as contained within the book of Genesis in the Bible. Thus many such people having chosen scientific evidence over the Genesis account, still believe in God, attend church, and participate in its ceremonialism.

[100] Classroom handout, Chapter 1 of the draft.

[101] Larry R. Stucki, "Copper Mines, Company Towns, Indians, Mexicans, Mormons, Masons, Jews, Muslims, Gays, Wombs, McDonalds, and the March of Dimes: "Survival of the Fittest" in and far beyond the Deserts of Arizona, New Mexico, and Utah," (Victoria, BC: Trafford Publishing, 2009),99; Malcom Gladwin, "The Tipping Point," (Boston, Little, Brown and Company, 2000), 9 .

[102] Clyde Kluckhohn and Dorothea Leighton, "The Navajo," (Cambridge, Massachusetts, Harvard University Press, Revised Edition 1974), 223.

[103] However, there are still many church-attending Navajos who joined as young people in the Mormon placement program (or in more recent times) who still attend traditional ceremonies such as the "Squaw Dance" or when confronted by a health crisis, not only seek a Mormon priesthood blessing but also, for good measure, seek help from a traditional "medicine man" despite enduring the continual chastisement of church leaders. 
[104] Fernando Santos, "Some Find Path to Navajo Roots Through Mormon Church," The New York Times, October 30, 2013.

[105] Ibid

[106] For example, at an annual Navajo Fair, a former Mormon placement student, Teddy Redhouse was being confronted by "radical Indians" because as a full-time missionary, he had cut his hair short and wore a suit. They challenged him saying: "Why don't you go back to Utah!" they charged, as they called him an "Apple," (accusing an Indian of having a thoroughly white core below a thin red skin). "Redhouse replied in Navajo, but quickly learned the two aggressive Indians did not speak their own Native language, and he likewise discounted their Indianness. If they did not know the language, he assumed, they surely did not know the culture and could not be true Navajos." Matthew Garrett, "Making Lamanites", (The University of Utah Press, 2016) 184.

[107] Mormons always refer to these secret rituals as being "sacred" not "secret" despite vows taken by members to never talk about them outside the temple nor reveal them to anyone (including other members who have not been given ecclesiastical permission to enter the temple and take the vows and learn the rituals).

[108] One afternoon at the employment center a very disturbed young man began confiding to my wife and I that he had made a terrible mistake by picking up a dead person and that he was now doomed. He then removed a shoe and sock to show us his toes that were turning black. My wife who had had several years of training to become a nurse immediately identified the problem as being caused by common nail fungus but he refused to believe her diagnosis. And, on another occasion, a Mormon bishop came into the center to tell us that his non-Mormon wife had just bought a plane ticket to fly to Texas to arrange for a traditional Navajo ceremony to prevent harm from coming to her granddaughter who had awakened from a "bad" dream of seeing and talking with her dead great-grandmother. This is an sharp contrast to what a Mormon grandmother would do where many members testify in meetings of the joy they have received when feeling the presence of deceased loved ones in dreams and in their holy temples.

[109] Reinforcing this rumor, several staff members who because of certain duties were alone in the building late at night, told me that they often heard unexplained footsteps and doors being opened and closed even though that they were positive that no other living person had been present in the building at the time.

[110] Linda M. Gerber, Review of Larry R. Stucki, "Copper Mines, Company Towns," American Indian Culture and Research Journal 34, no. 4 (2010): 109-112.

[111] Bill Donovan, "New book promotes Naat'aani Development Corp.," Navajo Times, June 29, 2017, A4 This high unemployment rate is also another important factor in the decline in fluency of the younger generation as more of them are forced to move to distant cities in search of employment. Donovan, then goes on to cite further statistics from the book, stating that, "Per capita income on the reservation for tribal members is $\$ 7,751$ as compared to $\$ 51,638$ for the U.S. as a whole." and "... that 43 percent of Navajos live below the poverty line and only 7.11 percent of Navajos have graduated from college with a bachelor's degree or higher."

[112] ibid., The figure cited is that " 62 cents of every dollar flows off the reservation." Much of this money is spent in the Walmart store in nearby Gallup, New Mexico that is rumored to be the most profitable of any Walmart store in America.

[113] Bill Donovan, "Alarming Crime Rates on Navajo," Navajo Times, January 21, 2016, A1.

[114] An extremely well liked dentist told the author that now that his children would be soon graduating from elementary school, he was resigning his position at the local medical center because the children would then be entering an extremely toxic environment in the higher grades.

[115] Several Navajos complained to me about the quality of care they were receiving at reservation hospitals and that reservation doctors often had failed to initially correctly diagnose serious life-threatening conditions in themselves and others they knew.

[116] The Major Crimes Act was passed by Congress after the U.S. Supreme Court's politically unpopular Ex parte Crow Dog decision where Crow Dog, a killer of a rival tribal leader, Spotted Tail, escaped being hanged for the murder when the Supreme Court ruled that the tribe's traditional way of resolving such a crime by having Crow Dog's clan compensate Spotted Tail's clan "with the payment of $\$ 600$, eight horses, and one blanket" should be honored as opposed to the usual way most non-Indian Americans strongly felt was the only proper way to deal with killers. (Lawrence Armand French, "Native American justice," Chicago, Burnham Inc., Publishers 2003, 135.)

[117] One of the "success" stories at our employment center occurred when the client having given up his drinking addiction, obtained full employment. However, only a month later he was brutally murdered by assailants who then stole his truck and all his tools. Despite this happening in a very small community where very few secrets would remain unknown, no significant investigation by the FBI ever occurred and the case remains unsolved.

[118] Bill Donovan, "Alarming Crime Rates on Navajo," Navajo Times, January 21, 2016, A1.

[119] Mike Cassidy, "When protesters took over Fairchild's lab on the Navajo reservation," San Jose Mercury News, October 23, 2012.

[120] The negotiations being coordinated by the author between the tribe and TW Services that were exploring the possible construction of a marina on Lake Powell at Antelope Point broke down at the last minute over this issue and the fear that this would lead to a battle with the rival holder of National Park concessions on the non-tribal shores of Lake Powell which could then possibly jeopardize TW Service's holdings in Zion National Park, Bryce Canyon National Park, and the North rim of Grand Canyon National Park.

[121] Any attempt by tribal leaders to round up these many thousands of wild animals always meets resistance not only from Navajos but also from very vocal outside pressure groups. Thus the one time suggestion by the tribal president to round them up and sell them to a slaughterhouse for export was quickly withdrawn and several attempts to remove them from especially overrun local areas, although requested by local leaders, faced fierce opposition from individuals who claimed that the roundup teams mistakenly not only removed wild horses but also some belonging to them. For many Navajos horse ownership is an essential status symbol. Thus one man coming into our employment center told us that after 
he realized that to protect his pastureland from overgrazing he had to let go of many of the 100 horses he "owned." For a more complete description of the many obstacles faced by tribal leaders as they attempt to solve this difficult problem made much more difficult by the extreme pressure being exerted upon them by the politically powerful "save the wild-horse" lobby, see Alysa Landry, "Controlling the Navajo Nation's Free-Roaming Horse Dilemma," Indian Country Today, August 24, 2017.

[122] Bill Donovan, "New book promotes Naat'aanii Development Corp," Navajo Times, June 29, 2016, A4.

[123] Ibid.

[124] Bill Donovan, " Gaming industry continues to flourish," Navajo Times, July 20, 2017, A1.

[125] Krista Allen, "Naabi green-lights purchase of Colorado ranch," Navajo Times, August 10, 2017, A4.

[126] The once-a-day bus from Window Rock to Gallup and return, although meeting the needs of those going there to shop, etc., was not considered to be a viable option for workers not having dependable and affordable vehicles. And on August third 2017 it was announced that the bus route to Gallup along with a number of other important routes had been shut down due to severe maintenance and financial problems that the overseer of the daily operations of the bus drivers bus routes blamed on the incompetence of the top two Navajo Transit officials who he states "have driven this program into the ground." (Terry Bowman, "Navajo Transit enduring many problems with funding," Navajo Times, August 3, 2017, A1.)

[127] This income can be considerable as reported by Raymond Friday Locke in his book, "The Book of The Navajo," where he states: "The singer is always paid in advance. The cost of a one or two night sing may be the equivalent of $\$ 50$ or under but a great nine-night chant such as the Mountain Top Way may cost a thousand dollars or more. A lengthy curing rite might tax the finances of the entire extended family." (Los Angeles, Mankind publishing company, sixth edition 2001, 48.)

[128] Most individuals on the reservation are living on land and in houses that are tribally owned and thus cannot be seized by off-reservation banks or other lenders.

[129] In addition to the collateral problem that potential entrepreneurs face is the demand by family members and friends to provide goods or services for free. This also applies to employed individuals such as a coworker at our employment center who had created many "enemies" in her local community by refusing to grant their often unreasonable "share the wealth" demands.

[130] Cindy Yurth, "Chinle water delays Denny's grand opening," Navajo Times, December 3, 2015, A2.

[131] An earlier adaptive change that gave a rising middle class on the reservation a chance to build equity by way of homeownership occurred in 1994 when the Navajo Nation's division of economic development purchased a parcel of this non-reservation land at St. Michaels and allowed a private developer to build an initial 151 homes on it. And, in sharp contrast to homes built on tribal trust land where homeowners are required to sell back the property through the tribal Council, which could require the purchaser to be a tribal member, these new Karigan Estate homes although initially requiring a family purchasing one to have at least one enrolled
Navajo member would allow the home to then be resold to anyone or be put up as collateral for a bank loan.(Rachel Peterson, "Building equity into native homes," Arizona Daily Sun, May 28, 2005.)

[132] Arlyssa Becenti, "Begaye: New tribal corp. could end unemployment in 3 years," Navajo Times, July 7, 2017, A2.

[133] Terry Bowman,'Tribal utility launches renewable energy program," Navajo Times, August 3, 2017, A7.

[134] A proposed safer way to again extract uranium, given what health problems had arisen during the earlier boom and bust uranium days, is no longer even being discussed.

[135] On December 21, 2015 this attraction recorded its record-breaking one-millionth visitor for 2015. (REGION BRIEFS, Navajo Times, December 30, 2015, C5.)

[136] For example, see a full page by " 10,000 boaters and backpackers," Navajo Times, November 23, 2016, A12.

[137] Alastair Lee Bitsoi, "Begaye does not support Arizona Escalade project," Navajo Times, May 14, 2015, A3.

[138] Elouise Barlow, Navajo Times, July 14, 2016, A6. For a strong opposing Letter to the Editor from a person in nearby Tuba City see Dolores Wilson-Aguine, Navajo Times, September 8, 2016, A7.

[139] R. Lamar Whitmer, "Letter to the Editor," Navajo Times, August 10, 2017, A6-7.

[140] Ibid

[141] Larry R. Stucki, "Supai: Wilderness Paradise or Prison?" Anthro Tech Vol. 5, No.2:8-13, (1981). (Unfortunately, I was not permitted to proofread the article before it was published and the editor told me that it was not possible for her to print a few very needed corrections in the next issue.) A corrected copy of this paper is available from the author. Also, available from the author: Larry R. Stucki, "An Economic Development Proposal for the Havasupai Reservation," April 11,1992 with a follow-up letter on April 8, 2009.

[142] For example, in San Juan County, Utah, even though Navajos outnumber non-Navajos (see Lee Davidson, "Key word for Utah's future: diversity," Salt Lake Tribune, June 22, 2017 , A1, A4.), they have been gerrymandered out of political power (see The Associated Press, "Election district boundaries violate rights of American Indians, judge rules," Salt Lake Tribune, July 21, 2017, B6.) and their pleas to protect the new Bears Ears monument from being eliminated or downsized have been completely ignored by Utah politicians and the Trump administration.

[143] Larry R. Stucki, “The Case Against Population Control: The Probable Creation of the First American Indian State," Human Organization 30, no. 4 (Winter 1971): 393-399.

[144] Arlyssa Becenti, "Weller says County partition proposal not racist," Navajo Times, March 10, 2016, A1. (Barry Weller is Apache County's only white supervisor.)

[145] ibid.

[146] Tribune Editorial Board, "Monumental error: Bear Ears review an act of spite," The Salt Lake Tribune, August 27, 2017, O1.

[147] Brian Maffly, "Tribes willing to go into battle," The Salt Lake 
Tribune August 26, 2017, A1,4. I vividly remember the day that I and the other new instructors at Navajo Community College followed Harry Walters to the top of the small mountain that was believed by Navajos to be the place where Changing Woman first appeared. As we climbed up to this revered site, passing the remains of early Navajo hogans, it was very disturbing to see the flames and smoke coming from nearby gas wells. And while on later faculty tours, again led by Harry Walters, but this time in the Butler Wash area of the new monument, we were again shown the remains of early hogans as proof that this area was also an integral part of the original Navajo homeland. Thus, I could well understand the fear of the Navajos and their allied tribes that such a drastic shrinkage of the Bears Ears Monument, if succeeding, would lead to scenes disturbingly similar to that I had earlier witnessed as we climbed Changing Woman's sacred hill in New Mexico. 